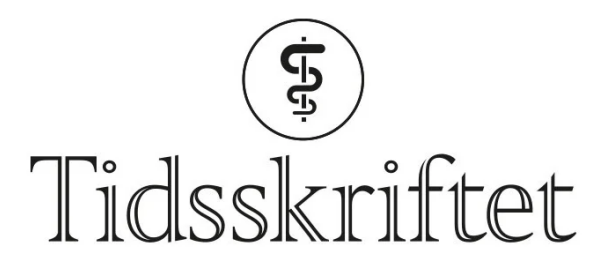

DEN NORSKE LEGEFORENING

\title{
Et bra supplement for den anatomistuderende
}

\author{
ANMELDELSER
}

PÅL GALTELAND

Avdelingsleder/overlege, kjeve- og ansiktskirurgisk avdeling Oslo universitetssykehus

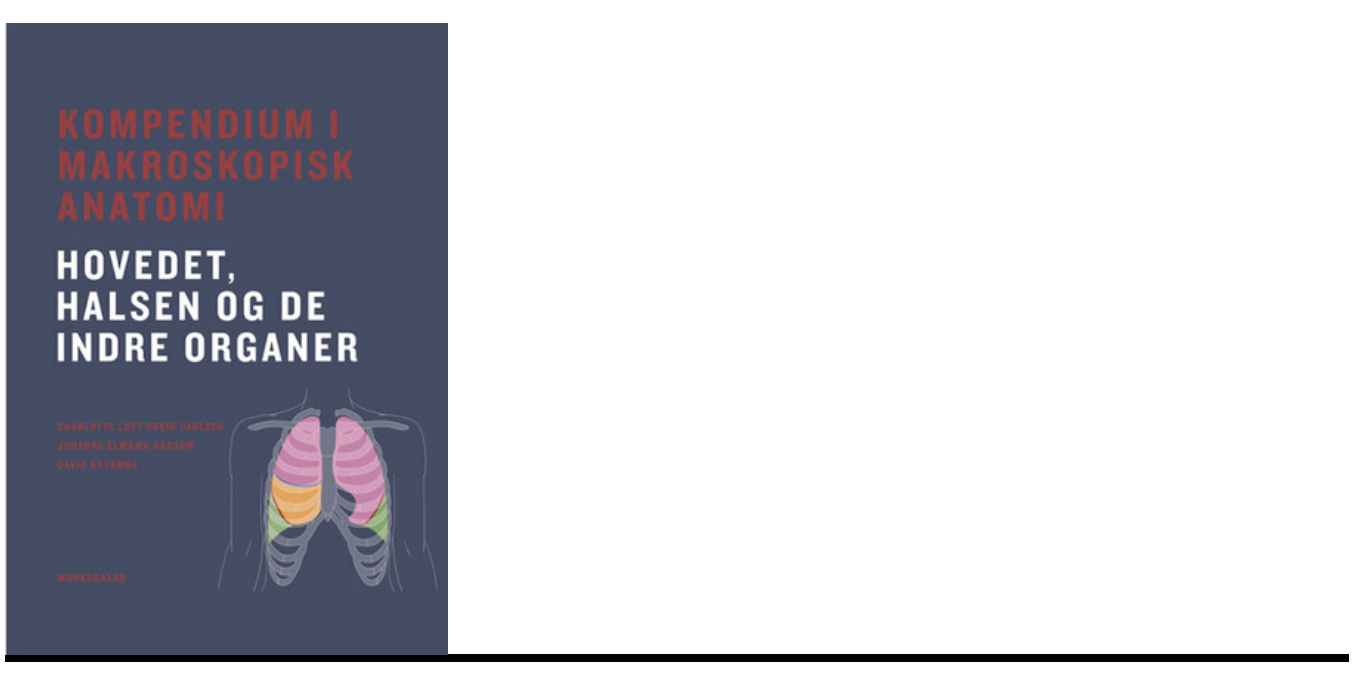

Charlotte Lott Breiø Carlsen, Johanne Elmbæk Kassow, David Kocemba

Kompendium i makroskopisk anatomi

Hovedet, halsen og de indre organer. 426 s, ill. København: Munksgaard, 2020. Pris DKK 395

ISBN 978-87-628-1947-4

Dette er et kompendium utarbeidet av tre medisinstudenter på Aarhus Universitet som har erfaring med å undervise medisinstudenter i makroskopisk anatomi. Boken henvender seg primært til medisin-, molekylær- og odontologistudenter. Intensjonen er å gi en oversiktlig og pedagogisk fremstilling av makroskopisk anatomi, før en gir seg i kast med mer detaljerte anatomibøker.

Boken er bygd opp i 31 kapitler. I første kapittel får man en enkel oversikt over kroppens ulike organsystemer med en grov innføring i kliniske undersøkelsesmetoder og billeddiagnostiske undersøkelser. De resterende kapitlene gir en systematisk oversikt over 
organene der en starter kranialt og går i sakral retning. Teksten er på dansk og er lett forståelig.

Kompendiet er rikt på illustrasjoner med bruk av fargekoder, slik at illustrasjon og tekst korresponderer. Det er også enkelte huskeregler som passer til fargekodene. For undertegnede synes en del av huskereglene å være litt for omfattende og mindre nyttige. Selv om dette er ment som en introduksjon til anatomi, er enkelte kapitler på et høyt detaljnivå. Som eksempel er orbitas og kjeveleddets anatomi beskrevet grundig og med fine illustrasjoner.

Mitt inntrykk er at denne boken også kan være til glede innen videreutdanning og spesialisering, og jeg kan anbefale den som et supplement til mer omfattende anatomibøker og anatomiske atlas.

Publisert: 16. august 2021. Tidsskr Nor Legeforen. DOI: 10.4045/tidsskr.21.0355

(C) Tidsskrift for Den norske legeforening 2023. Lastet ned fra tidsskriftet.no 26. april 2023. 